\title{
49. SHIPBOARD ORGANIC GEOCHEMISTRY
}

\author{
William E. Harrison, Oklahoma Geological Survey, University of Oklahoma, Norman, Oklahoma \\ and \\ Jean L. LaPorte, Institut Francais du Petrole, Rueil-Malmaison, France
}

\section{INTRODUCTION}

The shipboard organic geochemistry effort is heavily oriented toward safety considerations. The vessel is not equipped with a drilling mud or blowout control system, and penetration into petroleum-bearing rocks constitutes a potentially dangerous situation, both from the standpoint of ship safety and the environment.

In order to better conduct analyses that may indicate the presence of hydrocarbons, the ship is equipped with three gas chromatographs. Gases are the most mobile of the components that comprise petroleum, so the diffusion and solubility characteristics of the low molecular weight hydrocarbons make them especially useful as indicators of petroleum.

Studies concerning hydrocarbon and radiometric anomalies that overlie hydrocarbon deposits have been reviewed by Armstrong and Heemstra (1973). They cite a case (p. 11) in which methane diffuses 4500 feet vertically and provides some 4000 moles/acre/year to the surface. In a typical case, a petroleum reservoir may have a diffusion halo tens to hundreds of feet above the accumulation. Although diffusion in isotropic media describes a sphere from the emitting source, diffusion of gaseous hydrocarbons is modified by properties of the encompassing rocks (i.e., subsurface water movement, porosity, permeability) and the diffusion front is not uniform. These mobile hydrocarbons can be detected in various positions relative to the accumulation (vertically, horizontally, and diagonally) and thus provide evidence of nearby petroleum.

Methane $\left(C_{1}\right)$ is the major component of natural gas and may be the result of biogenic activity or of thermally controlled chemical reactions. Biogenic natural gas is extremely "dry," that is, it is mainly $\mathrm{C}_{1}$ with the $\mathrm{C}_{2}$ (ethane) and heavier components absent or nearly so. In contrast, thermally derived gas invariably contains quantities of the $\mathrm{C}_{2}+$ hydrocarbons (ethane and heavier), which can range from less than 1 per cent to over 20 per cent. The dominance of $C_{1}$ in biogenic gas is useful in assessing the origin of particular hydrocarbon gases.

The parameter used during Leg 48 was a measure of $\mathrm{C}_{1}$ (the dominant biogenic product) to heavier hydrocarbon species (which are not biogenic species). The $\mathrm{C}_{1} / \mathrm{C}_{2}+$ ratio was used to help predict proximity to petroleum deposits, so that excessively low values of this ratio may warrant abandoning a drill site.

\section{Safety}

With the addition of a flame ionization detector (FID) gas chromatograph on Leg 47A, shipboard analytical capability for detecting gaseous hydrocarbons was greatly enhanced. At present, $C_{1}-C_{5}$ components are determined, and significant quantities of the heavier species $\left(\mathrm{C}_{2}-\mathrm{C}_{5}\right)$ and low $\mathrm{C}_{1} / \mathrm{C}_{2}$ ratios are interpreted as a measure of proximity to petroleum. The current program involves simultaneous operation of three gas chromatographs (GC's) as well as fluorometric evaluation of possible hydrocarbon stains.

Also aboard for Leg 48 was the prototype of an Institut Francais du Petrole (IFP) instrument for determining (1) quantity of indigenous hydrocarbons in the sediment, (2) quantity of hydrocarbons that can be generated by pyrolysis $\left(\sim 550^{\circ} \mathrm{C}\right)$ of the sediment, and (3) approximate measure of the thermal evolution of the sediments (maturity).

The routine procedure for hydrocarbon monitoring during Leg 48 is outlined in Figure 1. Because of varying sensitivities and analysis time for methods used to determine the presence of hydrocarbons, priorities were assessed as follows:

Analysis by gas chromatography - quickest and most sensitive; presently restricted to $\mathrm{C}_{1}-\mathrm{C}_{5}$ components; samples taken as soon as cores are recovered.

Fluoroscope determinations-requires slabbing; response due to heavier hydrocarbon components.

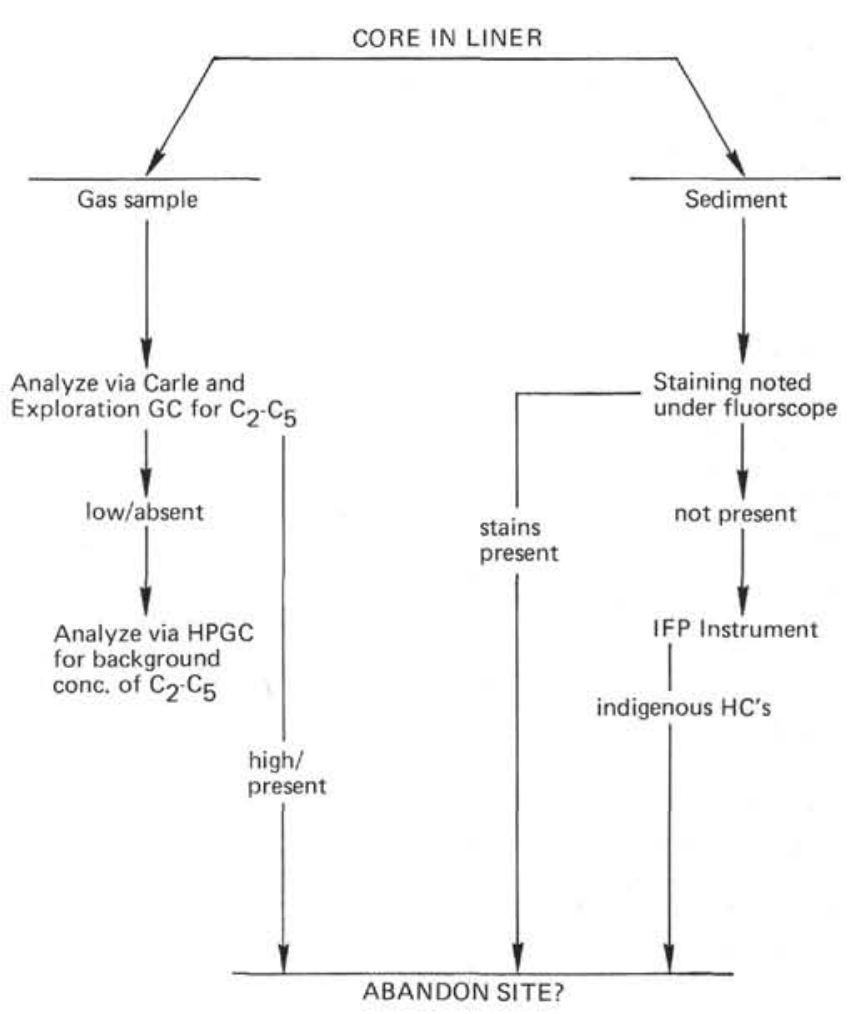

Figure 1. Hydrocarbon-monitoring program used on Leg 48. 
Pyrolysis determinations-requires slabbing; response due to broad spectrum of hydrocarbon components, both indigenous and those generated by pyrolysis.

\section{Analysis By Gas Chromatography}

Samples were collected as soon as cores were recovered by puncturing the plastic core liner and drawing gas samples into an evacuated vial (Vacutainers). Analyses were performed in the sequence indicated in Figure 1. Complete $\mathrm{C}_{1}-\mathrm{C}_{5}$ analysis with the Exploration Logging GC requires about six minutes. Sensitivity of these two instruments is such that concentrations of $\mathrm{C}_{1}-\mathrm{C}_{5}$ components must be on the order of tenths of a percent for detection.

The Hewlett-Packard GC (HPGC) is considerably more sensitive than the Carle and Exploration Logging instruments and is capable of detection of gaseous hydrocarbons in the sub-ppm range. Analysis time on the Hewlett-Packard was 22-24 minutes. A cold trap was used to strip methane $\left(C_{1}\right)$.

None of the gas samples analyzed during Leg 48 had $\mathrm{C}_{1}-\mathrm{C}_{5}$ concentration greater than concentrations found in rig-floor air samples.

\section{Fluorescence Analysis}

Samples from the slabbed cores were routinely analyzed, particularly when lithologic breaks were encountered, for detection of hydrocarbon staining. None of the samples analyzed during Leg 48 indicated the presence of hydrocarbons.

\section{Pyrolysis Studies}

An instrument (Girdel "'Rock-Eval') designed by IFP for evaluating hydrocarbon source rock quality and maturity, and indigenous hydrocarbon content, was put aboard in Brest and was used on Leg 48.

Several investigators have shown pyrolysis techniques to be useful for assessing hydrocarbon source potential and maturity level of organic-rich sediments (Giraud, 1970; Barker, 1974; Claypool and Reed, 1976).

In petroleum exploration programs, it is important to make three assessments regarding source rock potential as early as possible. These are (1) the type of organic matter contained in the sediments, (2) the quality of potential source-rock sequences, and (3) the maturity level.

Several papers (Forsman, 1963; McIver, 1967; Durand and Espitalié, 1973; Espitalié et al., 1973; Tissot et al.,1974) have demonstrated that it is possible to recognize several types of kerogen on the basis of physical and chemical properties. Three types of kerogen are distinguished on the basis of their elemental distribution of $\mathrm{C}, \mathrm{H}$, and $\mathrm{O}$ (Figure 2 ). The chemical and physical characteristics of the three types of kerogen, as well as changes due to maturity, have been discussed thoroughly by Espitalié et al. (1977).

The data of Figure 2 were obtained by acid destruction of the silicate minerals and concentration and purification of the organic residue (kerogen). Although this technique is time consuming, it has become a fairly common method to assess hydrocarbon source rock potential and maturity level.

The Girdel "'Rock-Eval"' achieves results similar to those of Figure 2 by means of pyrolysis (Espitalié et al., 1977). The pyrolysis technique is rapid (20-30 minutes/sample) and requires no sample preparation. Figure 3 shows data obtained by pyrolysis for the samples shown in Figure 2 . The three-

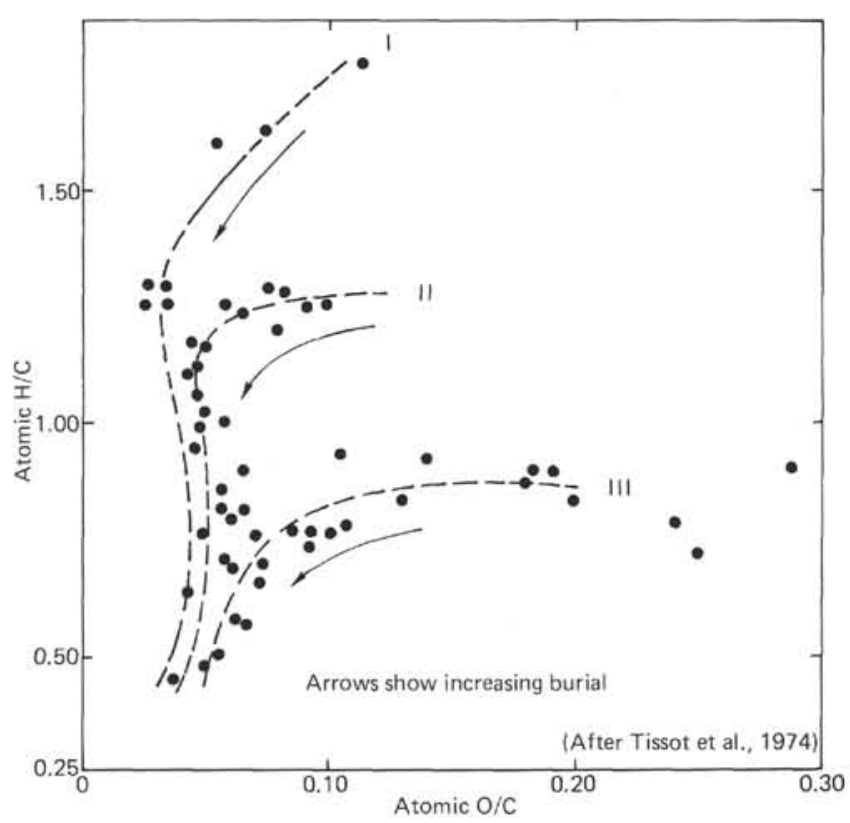

Figure 2. Elemental ratios of various types of kerogen. Type I kerogen has a high $\mathrm{H} / \mathrm{C}$ ratio and is typical of lipid-rich (algal) sediments. Type III kerogen is composed of humic or lignitic material and has relatively poor hydrocarbon-source potential. Type II kerogen has intermediate elemental ratio and hydrocarbon source characteristics.

fold subdivision of kerogen types is quite obvious, as are the changes that result from diagenesis. Hydrogen and oxygen indexes are total hydrocarbons generated by pyrolysis and total carbon dioxide yield, respectively; both values are normalized to organic-carbon content.

Figure 4 depicts the general operation of the instrument. The technique involves heating a small $(\sim 100 \mathrm{mg}$ ) rock sample at $200^{\circ}-250^{\circ} \mathrm{C}$ for a few minutes and then temperature programming the pyrolysis cell to $540^{\circ}-550^{\circ} \mathrm{C}$. Free hydrocarbons that are indigenous to the sediments (either syngenetic or migrated) are volatilized at the lower temperature and are swept to an FID where the total yield is quantified. The quantity of hydrocarbons thus obtained is called $S_{1}$. After $S_{1}$ products are swept from the furnace, the temperature program is initiated and the sample heated to $540^{\circ}-550^{\circ} \mathrm{C}$ at $25^{\circ} \mathrm{C} /$ minute. Hydrocarbons generated by these elevated temperature conditions are called $\mathrm{S}_{2}$ and represent the hydrocarbon-generating potential of the sample.

The $S_{1} / S_{2}$ ratio, $S_{1} / S_{1}+S_{2}$ ratio, and temperature of maximum pyrolysis yield may be used as indices of maturity (Espitalié et al., 1977). The $S_{1} / S_{2}$ ratio also may be used to evaluate shows and/or producible hydrocarbons (Espitalié et al., 1977).

Figure 5 shows variation in $S_{2}$ yield for selected Bay of Biscay sample. The small quantity of organic matter in samples described as clay-nannofossil mud is reflected by the lack of a distinct peak during programmed pyrolysis (Figure 5A). Another samples of clay-nannofossil mud (Figure 5B) yielded $0.20 \mathrm{mg}$ hydrocarbons per gm of rock. The third sample (Figure 5C) was also a clay-nannofossil mud, but sapropelic material was indicated in the smear slide description. The total quantity of hydrocarbons generated from 


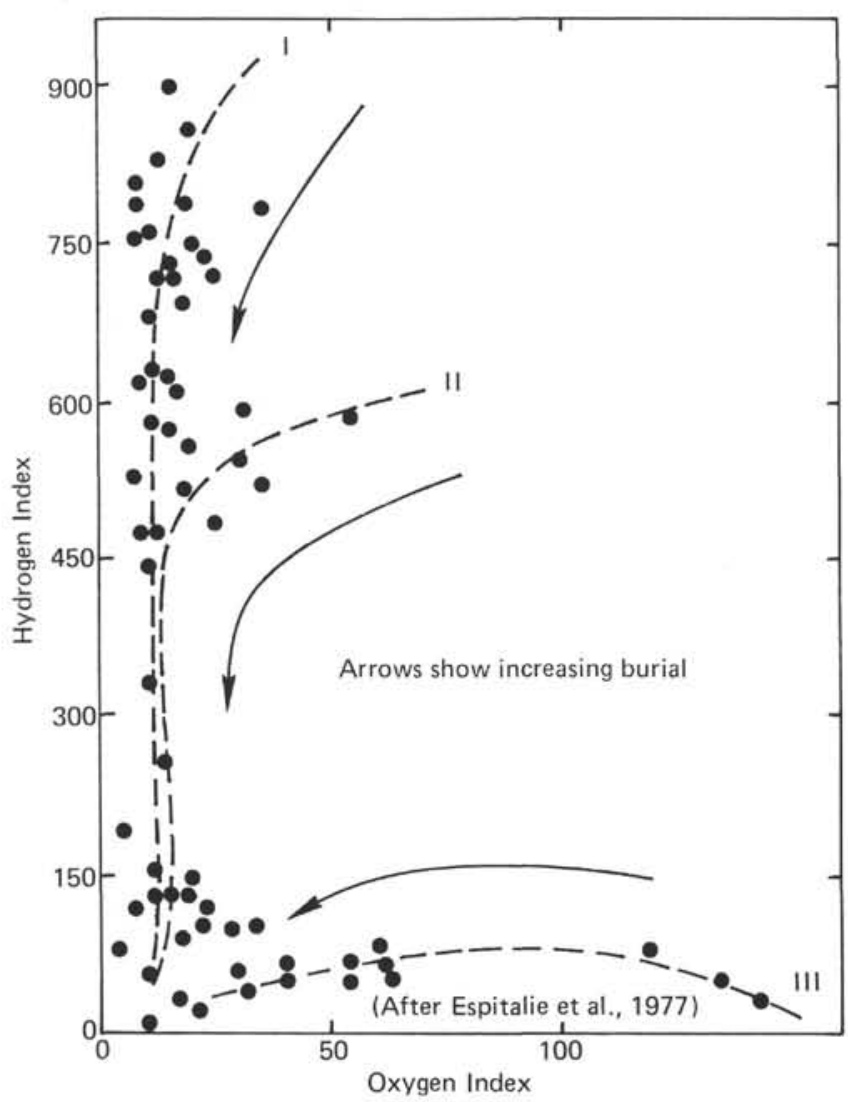

Figure 3. Classification of kerogen types by pyrolysis. Kerogen types I, II, and III are the same as Figure 2. Hydrocarbon Index and Oxygen Index represent total hydrocarbons generated by pyrolysis and $\mathrm{CO}_{2}$ yield, respectively, both normalized to organic carbon content.

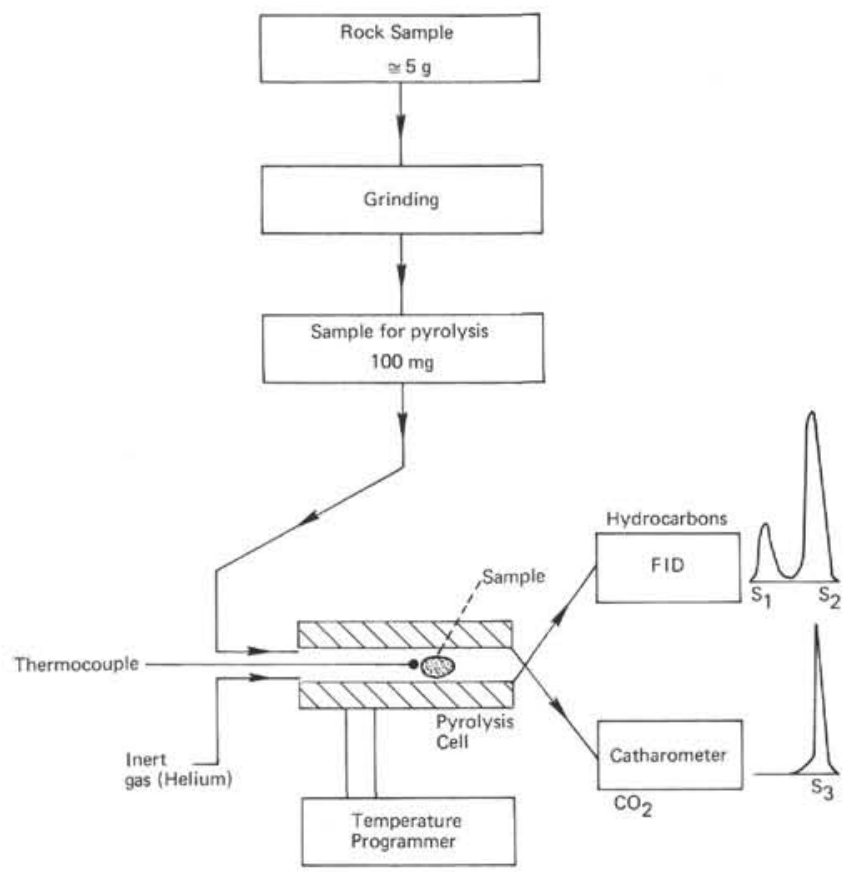

Figure 4. Schematic diagram showing sample preparation and general operation of the Girdel "Rock-Eval", see text for discussion.

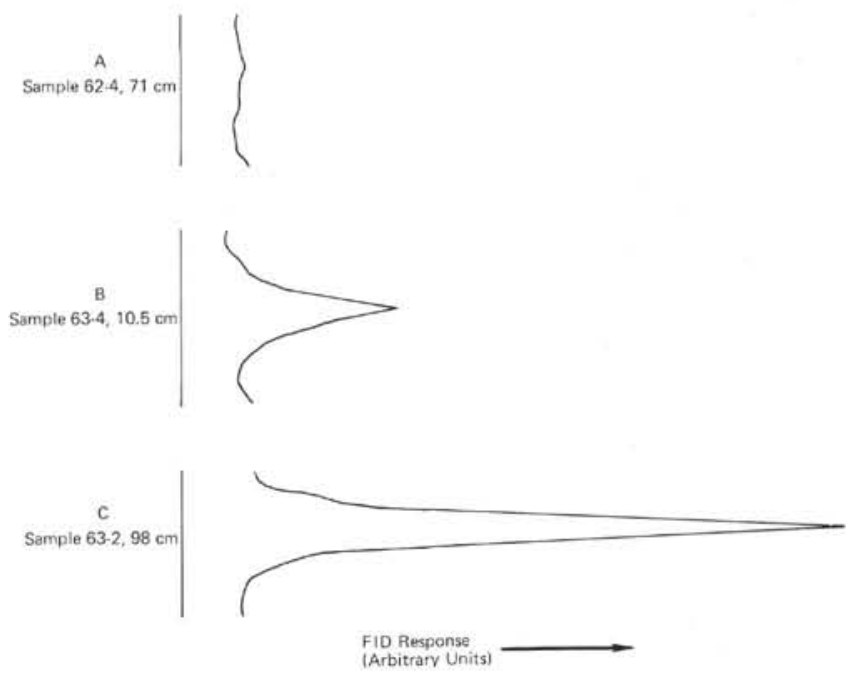

Figure 5. Varation in $S_{2}$ yield (hydrocarbons generated by pyrolysis) for selected samples from Bay of Biscay. (A) Clay-nannofossil mud; $S_{2}$ yield less than $0.10 \mathrm{mg}$ hydrocarbon per gram rock sample. (B) Clay-nannofossil mud; $S_{2}$ yield $0.20 \mathrm{mg}$ hydrocarbon per gram rock sample. (C) Clay-nannofossil mud with sapropel; $S_{2}$ yield $0.60 \mathrm{mg}$ hydrocarbon per gram rock sample.

Sample $63-2,98 \mathrm{~cm}$ by pyrolysis was $0.60 \mathrm{mg}$ per $\mathrm{gm}$ of rock.

The general increase in temperature of maximum pyrolysis yield (Figures 6,7) may reflect increasing stability of sedimentary organic matter as a function of geologic age. More stable organic matter requires higher temperatures to initiate reactions. Significant departures from the uniform increase in temperature of maximum pyrolysis yield are probably due to different types of organic material or reworked organic matter.

Generally, Leg 48 samples analyzed by pyrolysis indicated (1) a lack of producible hydrocarbons and shows, (2) an immature thermal history, and (3) poor hydrocarbon-source potential. Some of the black shales penetrated at sites in the Bay of Biscay have limited source potential under more favorable temperature conditions.

\section{RESULTS}

Sites 399, 400, and Hole 400A

\section{Gaseous Hydrocarbons}

Gas samples taken from Sites 399, 400 and Hole 400A cores were essentially barren of $\mathrm{C}_{1}-\mathrm{C}_{5}$ gaseous hydrocarbons. None of the analyzed samples contained $\mathrm{C}_{1}-\mathrm{C}_{5}$ concentrations greater than levels contained in rig floor air samples.

\section{Fluorescence Analysis}

None of the samples analyzed by fluorometry showed the presence of hydrocarbons.

\section{Pyrolysis Studies}

Figure 6 shows the results of shipboard pyrolysis studies of Hole 400A samples. Yields of $S_{1}$ (syngenetic and/or migrated hydrocarbons) were low, usually less than $2 \mathrm{mg}$ hydrocarbon/100 g rock. Hydrocarbons generated by prog- 


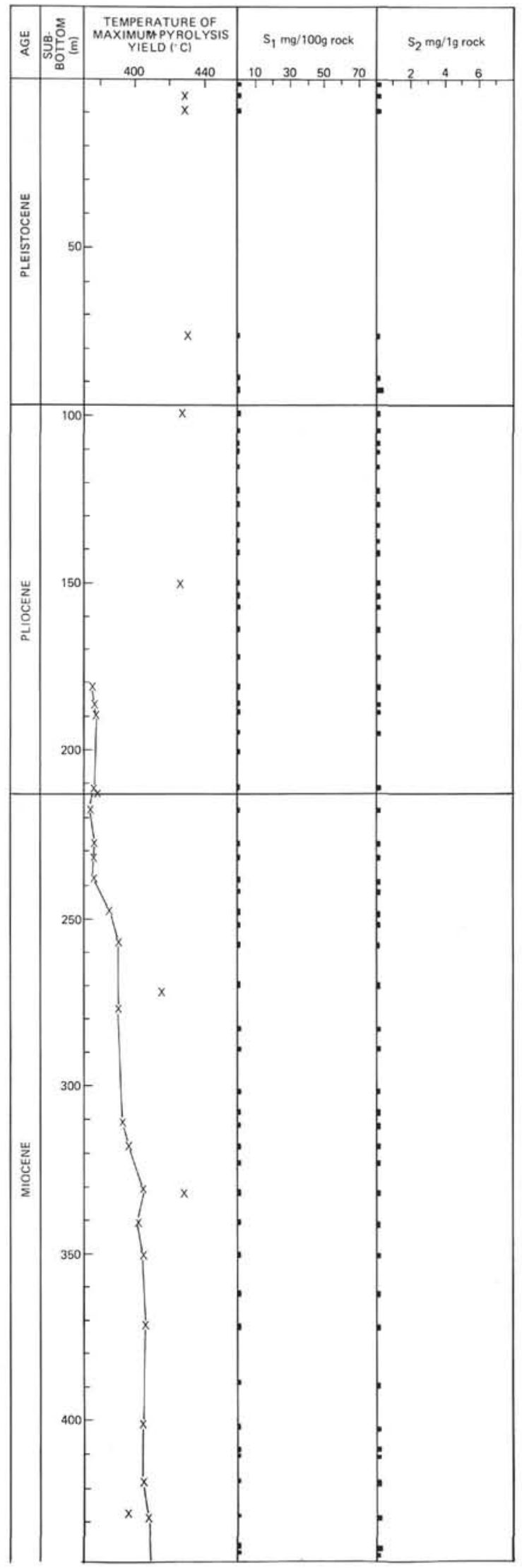

Figure 6. Pyrolysis data for Hole $400 \mathrm{~A}$ samples. $S_{1}$ represents indigenous hydrocarbons, and $S_{2}$ represents hydrocarbons generated by pyrolysis.

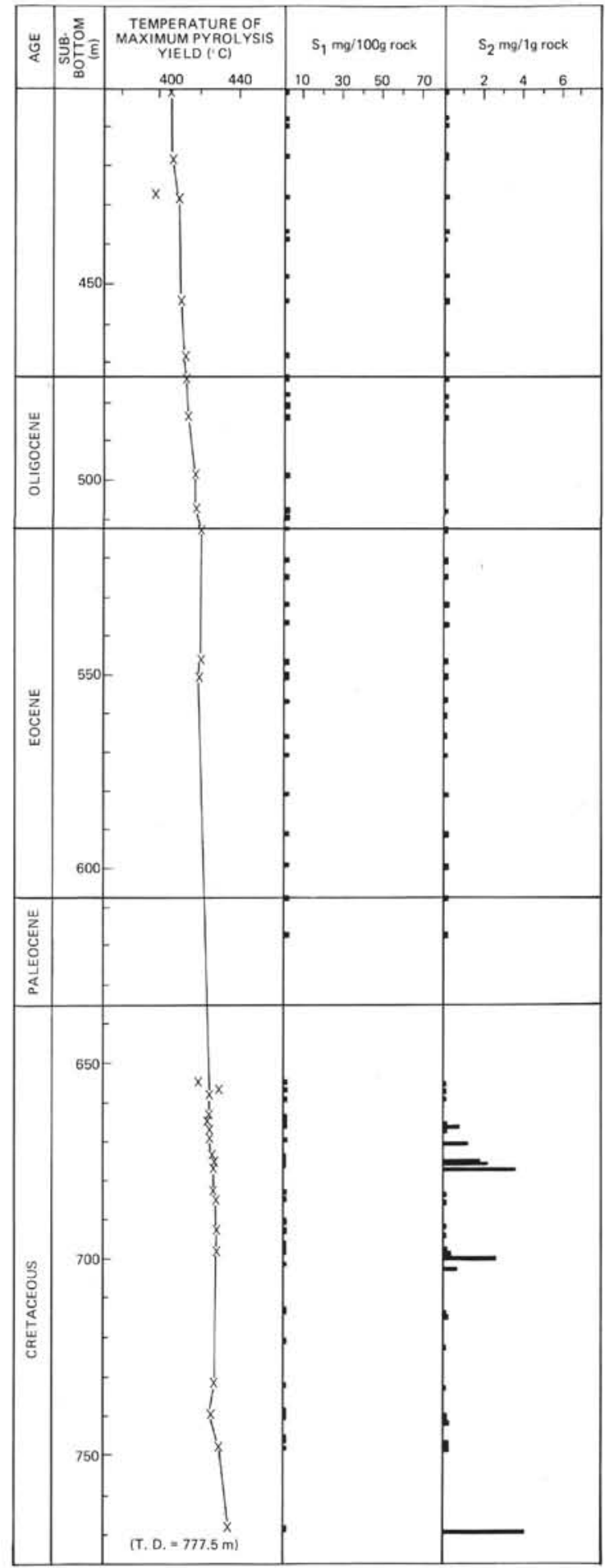

Figure 6. (Continued).

rammed pyrolysis, $\mathrm{S}_{2}$, were also generally low (Figure 6). The Cretaceous black shales penetrated at sub-bottom depths of 658 to 777.5 meters (total depth) had somewhat greater $\mathrm{S}_{2}$ yields. The maximum $S_{2}$ yield for black shale samples indicates that the penetrated sequence (1) has experienced a relatively low temperature history, (2) is barren of significant quantitites of hydrocarbons, and (3) has generally poor hydrocarbon source rock potential. The Cretaceous black shales penetrated at Hole 400A may have limited source potential under more favorable temperature conditions. 


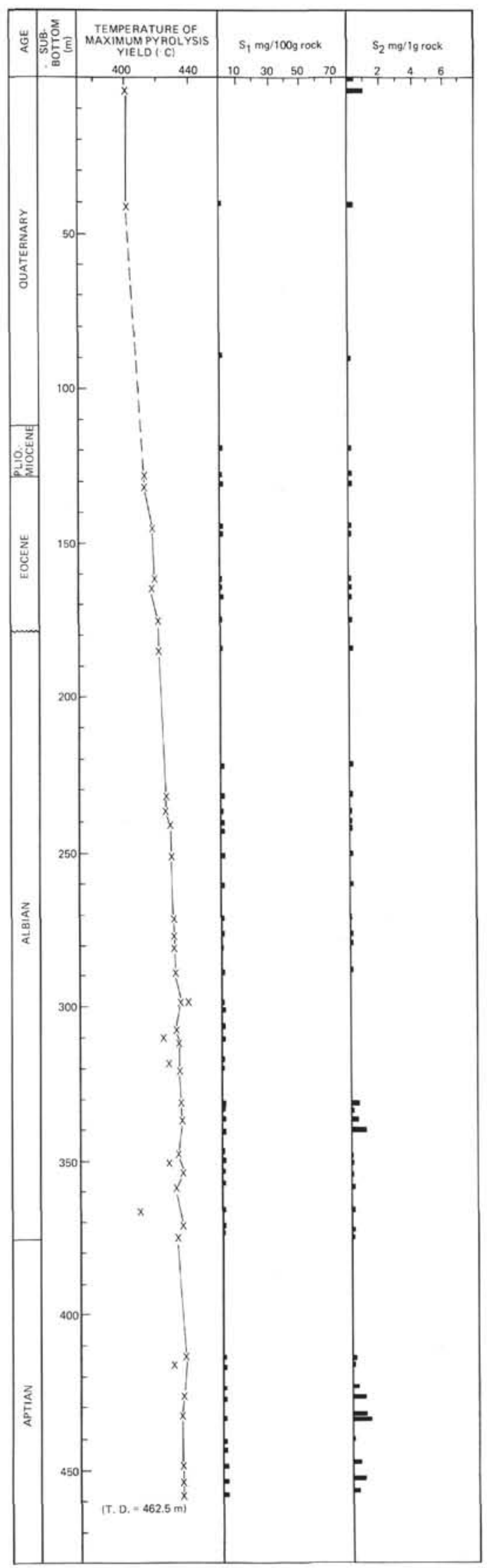

Figure 7. Pyrolysis data for Site 402 and Hole $402 \mathrm{~A}$ samples. Parameters as for Figure 6.
Site 401

\section{Gaseous Hydrocarbons}

None of the Site 401 samples showed the presence of significant quantities of $\mathrm{C}_{1}-\mathrm{C}_{5}$ hydrocarbons. Concentration levels were never greater than those encountered in rig floor air samples.

\section{Fluorescence Analysis}

None of the samples analyzed by fluorometry indicated the presence of hydrocarbons.

\section{Pyrolysis Studies}

Indigenous hydrocarbon yield $\left(\mathrm{S}_{1}\right)$ and hydrocarbons generated by programmed pyrolysis $\left(\mathrm{S}_{2}\right.$ yield) were low. Low $\mathrm{S}_{2}$ yields indicate poor hydrocarbon source potential, even under optimum temperature conditions.

\section{Holes 402/402A}

\section{Gaseous Hydrocarbons}

Holes 402/402A samples did not contain significant quantities of $\mathrm{C}_{1}-\mathrm{C}_{5}$ hydrocarbons.

\section{Fluorescence Analysis}

Fluorometric analysis indicated that Holes 402/402A samples were barren of hydrocarbons.

\section{Pyrolysis Studies}

The $S_{1}$ (indigenous) and $S_{2}$ (generated by pyrolysis) hydrocarbon yields were low for Holes 402/402A samples (Figure 7). Pyrolysis data helped make interpretations concerning the Cretaceous black shales which otherwise might not have been made. To illustrate this point, a comparison of particulate organic matter in the black shales at Holes 400A and $402 \mathrm{~A}$ is helpful.

At Hole 400A, the particulate organic matter in the smear slides consists of a mixture of two types of material. One type is yellow to brown, amorphous, translucent organic material; the second type is opaque (highly carbonized) plant debris. At Hole $402 \mathrm{~A}$, the organic matter is predominantly plant debris; several smear slides contain material that still retains some of the original cellular structures. In the absence of additional information, several conclusions might have been made on the basis of the above observation: (1) chemically reducing conditions prevailed during the time of deposition of the Albian-Aptian shales; (2) the high degree of carbonization of the sedimentary organic matter suggests a relatively high temperature history; (3) the presence of an organic-rich shale, a high thermal history, and suitable reservoir rocks (Site 401-Lower Cretaceous-Upper Jurassic reefal limestones) are all indications of a potentially petroliferous province.

A combination of the pyrolysis data and some basic knowledge of the nature of particulate organic matter in sediments permit a tentative conclusion quite different from the three assessments made above.

Lipid-rich or sapropelic organic matter in sediments (Types 1 and II of Tissot et al., 1974) owes its origin to metabolically derived fats, waxes, and oils. Lipids possess greater chemical stability than many other types of biochemi- 
cals and hence stand a better chance of being incorporated into sedimentary sequences. Because the precursor biochemicals are essentially amorphous, the degraded organic matter deposited in sediments is also amorphous. Such material is found in predominantly marine sediments and is considered to be due to biochemical input from Protistids (i.e., algae).

Humic-rich or lignitic material is due to structural material (cellulose and lignin) derived from higher plant debris. This material (Type III of Tissot et al., 1974) is highly structured, and cellular morphology is maintained even into higher coal rank. Lignitic material is usually associated with terrestrial sources. As a working principle, amorphous organic matter may be regarded as being due to lipid precursors and associated with predominantly marine biochemical input. Similarly, structured sedimentary organic material is most likely derived from cellulose, lignin, or a similar structural material and represents terrestrial biochemical input.

Maturity data derived from pyrolysis of samples from Site 400 and Hole 402A indicate a very low temperature history. This suggests that the organic matter in the black shales did not attain its highly carbonized state after deposition and must be detrital. Less translucent organic matter and increased concentrations of carbonized plant debris at Hole $402 \mathrm{~A}$ indicate greater input of terrestrial material.

Sites 403, 404, 405, 406

\section{Gaseous Hydrocarbons}

Gas samples were essentially barren of $\mathrm{C}_{1}-\mathrm{C}_{5}$ gaseous hydrocarbons.

\section{Fluorescence Analysis}

None of the samples analyzed by fluorometry showed the presence of hydrocarbons.

\section{Pyrolysis Studies}

Both $\mathrm{S}_{1}$ and $\mathrm{S}_{2}$ hydrocarbon yields were low and indicate a lack of indigenous hydrocarbons and source potential, respectively.

\section{ACKNOWLEDGMENTS}

We would like to thank IFP for permitting shipboard use of the Girdel "'Rock-Eval" during Leg 48. We would also like to thank B. Tissot and Colin Barker for reviewing the manuscript.

\section{REFERENCES}

Armstrong, F.E. and Heemstra, R.J., 1973. Radiation halos and hydrocarbon reservoirs: A review, U.S. Bur. Mines, IC 8579.

Barker, C., 1974. Pyrolysis techniques for source-rock evaluation, Am. Assoc. Petrol. Geol. Bull., v. 58, p. 2349-2361.

Claypool, G.E. and Reed, P.R., 1976. Thermal analysis technique for source-rock evaluation: Quantitative estimate of organic richness and effects of lithologic variation, Am. Assoc. Petrol. Geol. Bull., v. 60, p. 608-612.

Durand, B. and Espitalié, J., 1973. Evolution de la matiere organique au cours de l'enfouissement des sediments, C.R. Acad. Sci. Paris, v. 276, p. 2253-3356.

Espitalié, J., Durand, B., Rossel, J.C., and Souron, C., 1973. Etude de la matiere organique insoluble (kerogene) des argiles du frarogue, en analyse thermique differentielle et en analyse thermogravimetrique, Rev. Inst. Francais Petrole, v. 28, n. 1, p. 37-66.

Espitalié, J., LaPorte, J.L., Madec, M., Marquis, F., LePlat, P., Paulet, J., and Boutefeu, A., 1977. Method rapide de caractérisation, des roches merés de leur potential Pétrolier et de leur degré d evolutionn, Rev. l' Institut Francais Pétrole, v. 32, p. 23-42.

Forsman, J.P., 1963. Geochemistry of kerogen. In Breger, I.A. (Ed.), New York, Pergamon Press., Organic geochemistry: Chapt. 5, p. 148-182.

Giraud, A., 1970. Application of pyrolysis and gas chromatography to geochemical characterization of kerogen in sedimentary rock, Am. Assoc. Petrol. Geol. Bull,, v. 54, p. 439-455.

McIver, R.D., 1967. Composition of Kerogen - clue to its role in the origin of petroleum. In Seventh World Petrol. Congr. Proc., v. 2: Barking, Essex (Elsevier Publ. Co., Ltd.), p. 25-36.

Tissot, B., Durand, B., Espitalié J., and Combaz, A., 1974. Influence of the nature and diagenesis of organic matter in the formation of petroleum, Am. Assoc. Petrol. Geol. Bull., v. 58, p. 499-506. 